\title{
Plasma lipoproteins from patients with poorly controlled diabetes mellitus and "in vitro" glycation of lipoproteins enhance the transfer rate of cholesteryl ester from HDL to apo-B-containing lipoproteins
}

\author{
M. Passarelli ${ }^{1}$, S. Catanozi ${ }^{1}$, E.R . N akandakare ${ }^{1}$, J.C. R ocha ${ }^{1}$, R . E . M orton ${ }^{2}$, A . F. M. Shimabukuro ${ }^{1}$, \\ E.C.R , Q uintão ${ }^{1}$ \\ ${ }^{1}$ Lipids Laboratory, LIM/10, University of São Paulo Medical School, São Paulo, Brazil \\ ${ }^{2}$ Department of Cell Biology, Cleveland Clinic Foundation, Cleveland, USA
}

Summary Alterations in the reverse cholesterol transport system have been described in diabetic mellitus patients in several but not all studies. Furthermore, recently published investigations suggest that a faster "in vitro" transfer rate of cholesteryl ester from high density lipoproteins to apoB-containing lipoproteins could be solely ascribed to variation of the plasma lipoprotein composition and concentration in the diabetic state. The present study analysed the influence of lipoprotein glycation on the cholesteryl ester transfer protein-mediated transfer of esterified cholesterol from high density lipoprotein and its subfractions to lighter density lipoproteins. For this purpose two sets of "in vitro" experiments were carried out utilizing:1) plasma lipoproteins drawn from diabetic and from normal subjects and; 2) normal lipoproteins or partially purified cholesteryl ester transfer protein submitted to "in vitro" glycation. The transfer rate of ${ }^{14} \mathrm{C}$-cholesteryl ester labelled HDL subfractions to low or very low density lipoproteins was measured in all experiments. After incubations with plasma $\mathrm{d}>1.21 \mathrm{~g} / \mathrm{ml}$ or with purified cholesteryl ester transfer protein, apoB-containing lipoproteins were precipitated with a dextran sulfate $/ \mathrm{MgCl}_{2}$ solution. The "in vitro" glycation of the partially purified cholesteryl ester transfer protein markedly impaired its activity. However, greater transfer rates were observed when lipoproteins from diabetic individuals or the "in vitro" glycated lipoproteins were utilized. This effect was attributed to glycation of the protein component of HDL. In conclusion, lipoprotein glycation elicits an enrichment of the apoB-containing lipoproteins with cholesteryl ester that is likely related to the premature atherosclerosis in patients with poorly controlled diabetes. [Diabetologia (1997) 40: 1085-1093]

Keywords Cholesteryl ester transfer, CETP, lipoprotein glycation, diabetes mellitus, atherogenesis.
Several factors may be responsible for the high prevalence of premature atherosclerosis in diabetes

Received: 14 January 1997 and in revised form: 7 May 1997

Corresponding author: Dr. E. C. R. Quintão, Lipids Laboratory (LIM-10), Faculdade Medicina USP, Av. Dr. Arnaldo, 455, $3^{\circ}$ s/3317, CEP 01246-903, São Paulo, Brazil

A bbreviations: LP, Lipoprotein; HDL, high density LP; LDL, low density LP; VLDL, very low density LP; CETP, cholesteryl ester transfer protein; LCAT, lecithin-cholesterol acyl transferase; TLC, thin layer chromatography; UC, unesterified cholesterol; CE, cholesteryl ester; C, control; G, glycated; D, diabetic; TBARS, thiobarbituric acid reactive substances; DTNB, 5, 5'dithio-bis-(2-Nitrobenzoic acid); TNBS, Trinitrobenzenesulfonic acid; TG, triglyceride. mellitus [1], including possible alterations in the reverse cholesterol transport system [2-7].

Plasma lipoproteins (LP) are continually modified intravascularly and in the interstitium due to enzymatic action and interchanges of lipid fractions and apolipoproteins $[2,8,9]$. The role of cholesteryl ester transfer protein (CETP) in intravascular cholesteryl ester (CE) transport has been fully reviewed [2,10-12]. In addition to promoting a bidirectional flux of cholesteryl ester between LP, CETP also mediates the heteromolecular exchange whereby triglyceride (TG)-rich LP gains $\mathrm{CE}$ and loses TG [13]. The direction of this flow is partially determined by the lipid composition of the LP involved $[14,15]$. 
The role of CETP in atherogenesis is controversial $[2,10,11,16]$. High levels of plasma CETP were reported in several dyslipidaemias that are clearly related to the development of premature atherosclerosis [17-21]. Further confusion on this issue arises from a recent population study suggesting that elevated plasma CETP levels protect against atherosclerosis [22], whereas elevated CETP concentrations in transgenic mice may facilitate the development of premature atherosclerosis [16].

Conflicting results have been obtained in several studies measuring CETP activity in diabetes: increased, diminished and no alterated cholesteryl ester transfer between lipoproteins has been reported in insulin-dependent and non-insulin-dependent diabetes (IDDM and NIDDM) [3-7, 23-25]. These discrepancies are likely to be related to the different methods used to measure the cholesteryl ester transfer between LP, and may also be ascribed to variable concentrations and compositions of the acceptor and donor LP utilized in the "in vitro" tests. For instance, the plasma concentration of CETP is consistently within the normal range in diabetes [4, 24], thus the faster transfer rate of cholesteryl ester from HDL to lighter density LP could be attributed to the higher levels of cholesteryl ester acceptor LPs in diabetic plasma in the majority of the studies reported so far $[3-7,24]$. Surprisingly, in all these investigations the role played by glycation of the plasma LPs has not been taken into account. Glycation is responsible for several metabolic disturbances: diminished binding and internalization of LP by fibroblasts [26-28], decreased LP lipase hydrolysis [29] and heparin-dependent binding capacity of TG-rich lipoproteins [30], enhanced rate of HDL [31] and diminished rate of LDL and VLDL catabolism in blood [29, 32], and reduced lecithin-cholesterol acyl transferase (LCAT) activity [33]. Furthermore, cholesteryl ester synthesis in macrophages is enhanced after internalization of glycated lipoproteins via specific receptors [34], and the HDL-receptor mediated cell cholesterol efflux is diminished by glycation of HDL [35].

The present investigation assesses whether glycation of the whole plasma LPs as well as of the LP components influences the process of cholesteryl ester transfer from HDL to apoB-containing LP, namely, the reverse cholesterol transport system.

\section{Subjects, materials and methods}

I solation of $L P$ and radiolabelling of $H D L$. Fasting blood from normal control (total cholesterol $=4.60 \pm 0.64 \mathrm{mmol} / \mathrm{l}$; triglycerides $=1.43 \pm 0.58 \mathrm{mmol} / \mathrm{l}$; plasma glucose $\leq 5.5 \mathrm{mmol} / \mathrm{l}$; $\mathrm{HbA}_{1 \mathrm{c}} \leq 80 \mathrm{~g} / \mathrm{l}, \mathrm{n}=11$ ) and from poorly controlled diabetic subjects (total cholesterol $=5.00 \pm 0.80 \mathrm{mmol} / \mathrm{l}$; triglycerides $=1.52 \pm 0.36 \mathrm{mmol} / \mathrm{l} ; \quad$ plasma glucose $\geq 16.6 \mathrm{mmol} / \mathrm{l}$; $\mathrm{HbA}_{1 \mathrm{c}} \geq 140 \mathrm{~g} / \mathrm{l}, \mathrm{n}=6$ ) was drawn over $2 \mathrm{mmol} / \mathrm{l}$ EDTA $(10 \mu \mathrm{l} / \mathrm{ml})$ and the following preservatives were added to the plasma pools: $2 \mathrm{mmol} / \mathrm{l}$ benzamidine $(5 \mu \mathrm{l} / \mathrm{ml}), 0.5 \%$ gentamicin plus $15 \mathrm{mmol} / \mathrm{l}$ chloramphenicol $(20 \mu \mathrm{l} / \mathrm{ml}), 0.5 \mathrm{mmol} / \mathrm{l}$ phenyl-methyl-sulfonyl-fluoride in DMSO $(0.5 \mu \mathrm{l} / \mathrm{ml})$, and aproti$\operatorname{nin}(10 \mu \mathrm{l} / \mathrm{ml})$. Plasma lipoproteins were separated by sequential ultracentrifugation [36]; VLDL was obtained at $d=1.006$ $\mathrm{g} / \mathrm{mL}$ for $12 \mathrm{~h}, 100000 \mathrm{~g}$ at $4{ }^{\circ} \mathrm{C}$ in an L-8 ultracentrifuge (Beckman Instruments, Palo Alto, Calif., USA); LDL was obtained at $\mathrm{d}=1.006-1.063 \mathrm{~g} / \mathrm{ml}$ for $20 \mathrm{~h}$. The LP were dialysed against phosphate buffered saline (PBS) $(150 \mathrm{mmol} / \mathrm{l} \mathrm{NaCl}, 20 \mathrm{mmol} /$ $1 \quad \mathrm{Na}_{2} \mathrm{HPO}_{4}, 14 \mathrm{mmol} / \mathrm{l} \quad \mathrm{NaH}_{2} \mathrm{PO}_{4}, 1 \mathrm{mmol} / \mathrm{l} \quad \mathrm{NaOH}$ and $0.2 \mathrm{mmol} / 1$ EDTA) and maintained at $4{ }^{\circ} \mathrm{C}$ after sterilization.

The $d>1.063 \mathrm{~g} / \mathrm{ml}$ fraction was labelled with $4{ }^{14} \mathrm{C}$-cholesterol (New England Nuclear, Boston, Mass., USA) at $4{ }^{\circ} \mathrm{C}$ for $48 \mathrm{~h}$ according to the method of Dobiasova et al. [37] or with (cholesteryl-4- ${ }^{14} \mathrm{C}$ ) oleate at $37^{\circ} \mathrm{C}$ for $24 \mathrm{~h}$. Isotope purity was previously checked by preparative thin-layer chromatography (TLC) [38] and shown to be greater than $95 \%$. In order to esterify $4-{ }^{14} \mathrm{C}$-cholesterol-HDL by the endogenous LCAT enzyme, the same $\mathrm{d}>1.063 \mathrm{~g} / \mathrm{ml}$ sample was incubated at $37^{\circ} \mathrm{C}$ for $48 \mathrm{~h}$ and $\mathrm{HDL}_{2}$ and $\mathrm{HDL}_{3}$ fractions were then separated by ultracentrifugation at density ranges $1.063-1.125$ and $1.125-1.210$ $\mathrm{g} / \mathrm{ml}$, respectively. HDL fractions were also dialysed against the phosphate buffer. Unesterified and esterified cholesterol were separated by thin layer chromatography (TLC) on silica gel $\mathrm{G}$ in a development system of hexane:ethyl ether:acetic acid (70:30:1, v:v:v), and the percent of $4-{ }^{14} \mathrm{C}$-cholesterol esterified was calculated. Radioactivity was determined in a toluene-Triton solution containing (1, 4-bis[2-(5-phenyloxazole)] benzene) and 2, 5 diphenyloxazole (0.5:5, g:g) in an LS6000TA beta scintillation counter (Beckman). LCAT-dependent esterification of ${ }^{14} \mathrm{C}$-cholesterol was $82 \%$ in $\mathrm{HDL}_{2}$ and $90 \%$ in $\mathrm{HDL}_{3}$, producing enough ${ }^{14} \mathrm{C}$-cholesteryl ester for the "in vitro" measurement of the cholesteryl ester transfer.

Total cholesterol (Chod-Pap, Merck S/A, São Paulo, Brazil), unesterified cholesterol (Boehringer Mannheim Biochemicals, Mannheim, Germany) and triglycerides (Enz-Color, Biadiagnostica, Pinhais PR, Brazil) were determined by enzymatic techniques. Protein was determined by the method of Lowry et al. [39]. Glycated haemoglobin $\left(\mathrm{HbA}_{1 \mathrm{c}}\right)$ was measured by the affinity column system Glyc-Affin Ghb (Isolab Inc., Akron, Ohio, USA). Phospholipids were analysed by the Bartlett procedure [40]. Apo A-I-lipoprotein was estimated by radioimmunoassay (Pharmacia Diagnostics AB, Uppsala, Sweden).

Purification of Human CETP. CETP was partially purified from human plasma by the method described by Morton and Zilversmit [41], using phenyl-Sepharose and CM-cellulose chromatography. This protein was purified 800 times relative to the LP-deficient plasma and was deficient in LCAT activity.

LP and CETP glycation. LPs were glycated by the procedure of Witztum et al.[26]. Briefly, $0.5 \mathrm{ml}$ of sterile $200 \mathrm{mmol} / \mathrm{l}$ glucose solution (Sigma Chemical Company, St. Louis, Mo., USA) in PBS with EDTA and preservatives, $\mathrm{pH}=7.35$, and $200 \mathrm{mmol} / \mathrm{l}$ of freshly prepared sodium cyanoborohydride $\left(\mathrm{NaCNBH}_{3}\right)($ Sigma) were added to $3 \mathrm{mg}$ of LP-protein and incubated in the dark for 4 days at $37^{\circ} \mathrm{C}$ in a water bath shaker. Control LP were similarly treated utilizing PBS alone. In order to identify a possible interference of the reducing agent itself, control incubations were also carried out with LP and glucose, or LP and $\mathrm{NaCNBH}_{3}$ alone. Control and glycated LP were then exhaustively dialysed against the PBS. Partially purified CETP (approximately $0.572 \mathrm{mg}$ of protein $/ \mathrm{ml}$ ) was glycated in the presence of sterile glucose $20 \mathrm{mmol} / \mathrm{l}$ in buffer $(15 \mathrm{mmol} / \mathrm{l}$ $\mathrm{Na}_{2} \mathrm{CO}_{3}, 35 \mathrm{mmol} / \mathrm{l} \mathrm{NaHCO} 3,3 \mathrm{mmol} / \mathrm{l} \mathrm{NaN}$ ), pH 7.4 and $200 \mathrm{mmol} / \mathrm{l}$ of $\mathrm{NaCNBH}_{3}$. Control incubations were carried out as described above. 
Control and "in vitro" glycated LP utilized in the incubations were re-isolated by sequential ultracentrifugation within their original density ranges. Purified LP were combined to provide a total cholesterol mass ratio of $3 / 1$ for $\mathrm{LDL} / \mathrm{HDL}_{2}$ or $\mathrm{HDL}_{3}$ and $1 / 1$ for $\mathrm{VLDL} / \mathrm{HDL}_{2}$ or $\mathrm{HDL}_{3}$ roughly approximating their ratios in normal plasma. In addition, in experiments where lipoproteins were drawn from diabetic subjects and normal control subjects, the concentrations of triglycerides in the acceptor lipoproteins (LDL or VLDL) and of cholesteryl ester in HDL, which is the donor of ${ }^{14} \mathrm{C}$-cholesteryl ester, were identical. The absence of thiobarbituric acid-reactive substances (TBARS) [42] demonstrated that the oxidation of the glycated LP did not occur. In addition, the sialic acid content of LPs from the diabetic subjects, and "in vitro" LP glycated was similar to that of control LP (data not shown).

M easurement of glycation. LP glycation both "in vitro" and "in vivo" was measured by the TNBS reaction [43]. Additionally the incorporation of $\left[2-{ }^{3} \mathrm{H}\right]-\mathrm{D}$-glucose (New England Nuclear) was utilized for the measurement of the extent of LP glycation "in vitro". After exhaustive dialysis the lipoprotein incorporation values of ${ }^{3} \mathrm{H}$-glucose disclosed that both the protein and the lipid components were simultaneously glycated. The degree of protein glycation was measured after extracting the lipid components with a mixture of chloroform:methanol $(2: 1$, $\mathrm{v}: \mathrm{v}$ ), overnight at $4{ }^{\circ} \mathrm{C}$, followed by exhaustive chloroform extraction. Extracted phospholipids were separated by TLC with chloroform: acetone: methanol: acetic acid: water (5:2:1:1:0.5; v:v:v:v:v). Phosphatidylethanolamine, lecithin, lysophosphatidylcholine, sphingomyelin and phosphatidylserine (Nu-Chek Prep. Incorporated, Elysian, Minn., USA) standards were utilized. Phospholipid bands were scraped into Acquasol (DuPont, Boston, Mass., USA) containing vials for radioactivity determination, whereas the protein-containing water phase was directly added to the radioactivity counting vials.

E lectrophoresis. In order to qualitatively check LP alterations elicited by the glucose modification samples LP were submitted to electrophoresis on $1 \%$ agarose gel [44] and stained with Oil red for apoB-containing LP and Sudan black for HDL subfractions.

Reconstitution of HDL. HDL from control plasma donors were separated by sequencial ultracentrifugation in the density range $1.085-1.21 \mathrm{~g} / \mathrm{ml}$ and purified by discontinuous gradient density ultracentrifugation. In order to delipidate HDL, after dialysis against PBS, HDL $(2 \mathrm{ml})$ was added to $40 \mathrm{ml}$ of ethanol:ethyl-ether $(3: 2, \mathrm{v}: \mathrm{v})$ containing $0.02 \mathrm{mmol} / \mathrm{l}$ of butylatedhydroxytoluene (BHT) and stored frozen for $3 \mathrm{~h}$ [45]. The solvent phase was aspirated after sample centrifugation for $15 \mathrm{~min}$ at $3000 \mathrm{rev} / \mathrm{min}$ at $4{ }^{\circ} \mathrm{C}$. The procedure was repeated with an additional overnight extraction with ethyl-ether. The lipid extracted phase was dried on a rotor-evaporator, re-diluited with ethyl-ether and transferred to vials containing $3 \mu \mathrm{Ci}$ of ${ }^{14} \mathrm{C}$-cholesteryl oleate. Both the lipid and the protein pellet were dried under $\mathrm{N}_{2}$ and immediately utilized in the experiments described below.

Both components were glycated by exposure to concentrated glucose and $\mathrm{NaCNBH}_{3}$, as described above. Also, this procedure was carried out on sonication in the Branson Cell Disruptor model 450, with a 3/8 titanium tip (Branson Sonifier, Danbury, USA) during $2 \mathrm{~min}$, at $40 \mathrm{~W}$, on an ice bath.

HDL particles were reconstituted by sonication of the lipid component during 2 cycles of 2 min each at $40 \mathrm{~W}$. The protein solution was then added to the lipid fraction and further sonified in 2-min bursts for $40 \mathrm{~min}$ with 2-min resting intervals to avoid temperature elevation. Reconstituted HDL (recHDL) was submitted to discontinuous gradient density ultracentrifugation at the $1.085-1.21 \mathrm{~g} / \mathrm{ml}$ density range. In addition experiments with ${ }^{3} \mathrm{H}$-glucose incorporation showed that the radioactivity was present solely in the LP fraction submitted to glycation.

A ssay of cholesteryl ester transfer protein activity. The transfer of ${ }^{14} \mathrm{C}$-cholesteryl ester from HDL to apoB-containing LP was carried out among several combinations of lipoproteins from normal control subjects and from diabetic subjects, as well as LP that were glycated "in vitro". Transfer rates were measured from 2 to $4 \mathrm{~h}$ incubation periods since previous studies have shown that radioactive transfer reflects cholesteryl ester mass transfer between LPs [46]. Incubations were done in the presence of CETP at $37^{\circ} \mathrm{C}$ and were properly corrected for blank values at $4^{\circ} \mathrm{C}$. Plasma $\mathrm{d}>1.21 \mathrm{~g} / \mathrm{ml}(200 \mu \mathrm{l})$ containing $0.25 \mathrm{mmol} / \mathrm{l}$ of 5,5 'dithio-bis-(2-Nitrobenzoic acid) (DTNB) $(5.5 \mu \mathrm{l} / \mathrm{ml}$ plasma) was utilized as a CETP source. Final incubation volumes were adjusted with Tris buffer $(10 \mathrm{mmol} / \mathrm{l}$ Tris; $150 \mathrm{mmol} / \mathrm{l} \mathrm{NaCl} ; 0.2 \mathrm{mmol} / \mathrm{l}$ EDTA; $4 \mathrm{mmol} / \mathrm{l} \mathrm{NaN}_{3}$ ). ApoBcontaining lipoproteins were precipitated with a dextran sulfate $/ \mathrm{MgCl}_{2}$ solution $\left(50 \mu \mathrm{l} / 500 \mu \mathrm{l}\right.$ of sample) and $\mathrm{HDL}_{2}$ or $\mathrm{HDL}_{3}$ radioactivity measured directly in the supernatant fraction, or after separation of the unesterified and esterified cholesterol components by TLC after correcting for TLC losses of radioactivity. Percent radioactivity transfer from HDL to LDL or VLDL was calculated as $[1-(\mathrm{X} / \mathrm{Y})] \times 100$, where: $\mathrm{X}={ }^{14} \mathrm{C}$-CE in the supernatant after incubation at $37^{\circ} \mathrm{C}$ with plasma $\mathrm{d}>1.21 \mathrm{~g} / \mathrm{ml}$; and $\mathrm{Y}={ }^{14} \mathrm{C}-\mathrm{CE}$ in the supernatant after incubation at $4^{\circ} \mathrm{C}$ with plasma $\mathrm{d}>1.21 \mathrm{~g} / \mathrm{ml}$.

A possible interference of glycation on LP precipitation with dextran sulphate/ $\mathrm{MgCl}_{2}$ was ruled out after measuring protein in the supernatant of the incubated control and glycated HDL or LDL that had previously been purified by ultracentrifugation.

In the assays utilizing partially purified CETP, the donor and acceptor control LP, ${ }^{14} \mathrm{C}$-cholesteryl ester $\mathrm{HDL}_{2}$ and LDL, respectively, were incubated either with control or with glycated CETP $(28 \mu \mathrm{g})$.

Statistical analyses. Mann Whitney test was used to compare median values of percent transfer. Two-tailed tests of significance were utilized and a $p$-value of less than 0.05 was considered statistically significant.

\section{Results}

M easurement of glycation. Incorporation of ${ }^{3} \mathrm{H}$-glucose into LP was time-dependent (Fig.1) and occurred simultaneously in the lipid and in the protein fractions, although clearly predominantly in the latter component (Fig.2). Furthermore, most of the lipid ${ }^{3} \mathrm{H}$-glucose content was present in the phosphatidylethanolamine moiety (data not shown). The percent of the protein lysine residues that were derivatized "in vitro" was estimated by the TNBS reaction (Fig.3). It was also shown that the percent of lysine residues that had been modified in LP obtained from diabetic subjects was approximately 70, 19, 24 and $19 \%$ for VLDL, LDL, $\mathrm{HDL}_{2}$ and $\mathrm{HDL}_{3}$, respectively.

E lectrophoresis. As compared to native LP, glycated LDL and VLDL moved faster on the agarose gel, 


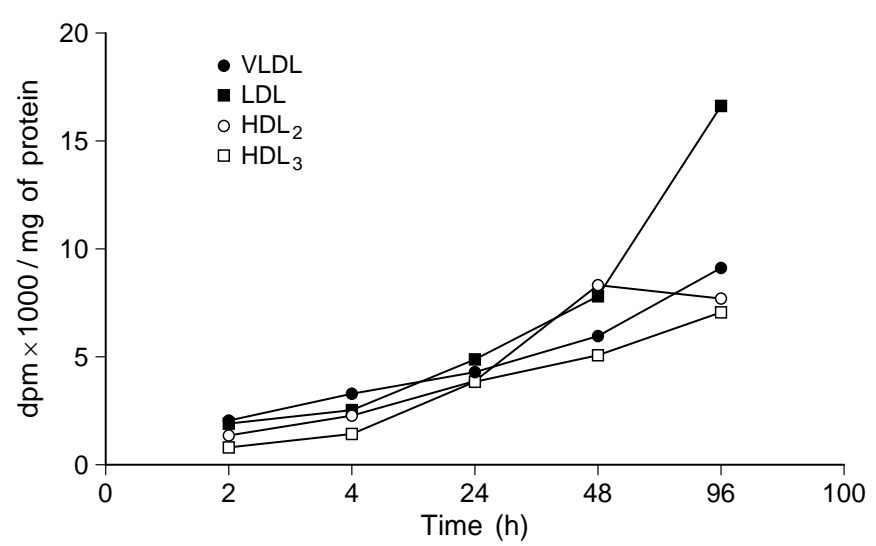

Fig. 1. Incorporation of ${ }^{3} \mathrm{H}$-glucose in plasma LP separated by sequential ultracentrifugation. LP glycation was carried out in sterile $200 \mathrm{mmol} / \mathrm{l}$ glucose solution and $\mathrm{NaCNBH}_{3}$ along time. Data expressed as radioactivity incorporated per $\mathrm{mg}$ of LPprotein (media of triplicate)
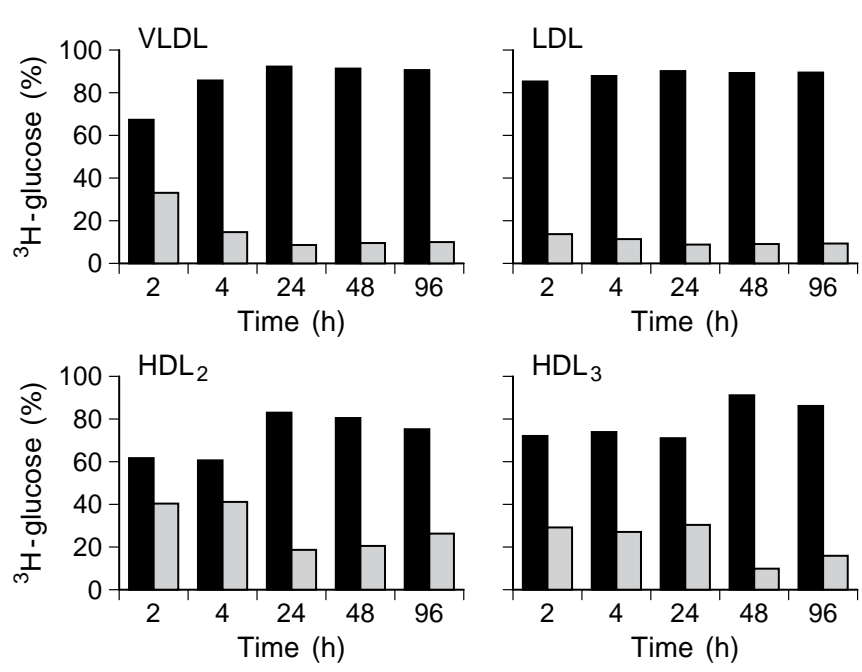

Fig. 2. Incorporation of ${ }^{3} \mathrm{H}$-glucose in plasma LP as shown in Figure 1. Data expressed as the percent ${ }^{3} \mathrm{H}$-glucose recovered in the protein $(\square)$ and lipid fractions $(\square)$ of plasma LP as a function of incubation time (triplicate experiments)

apparently due to the glycation of the $\mathrm{NH}_{3}$ groups, particularly of Lys and Arg [26, 30]. As for the $\mathrm{HDL}_{2}$ and $\mathrm{HDL}_{3}$ fractions, glucose incorporation had no influence on their migration pattern (Fig.4) as previously shown by Fournier et al. [33]. In regard to apoB containing-LP or HDL migration rates were similar for LP from diabetic patients and from the control subjects.

$M$ easurement of the $E$ sterification Rate. In the presence of plasma $\mathrm{d}>1.21 \mathrm{~g} / \mathrm{ml}$ as the source of LCAT a $50 \%$ decrease of the esterification rate of cholesterol occurred in assays carried out with glycated HDL: esterification values were $76 \%$ in $\mathrm{HDL}_{2}$ control, $33 \%$ in $\mathrm{HDL}_{2}$ glycated, $82 \%$ in $\mathrm{HDL}_{3}$ control and $40 \%$ in $\mathrm{HDL}_{3}$ glycated.

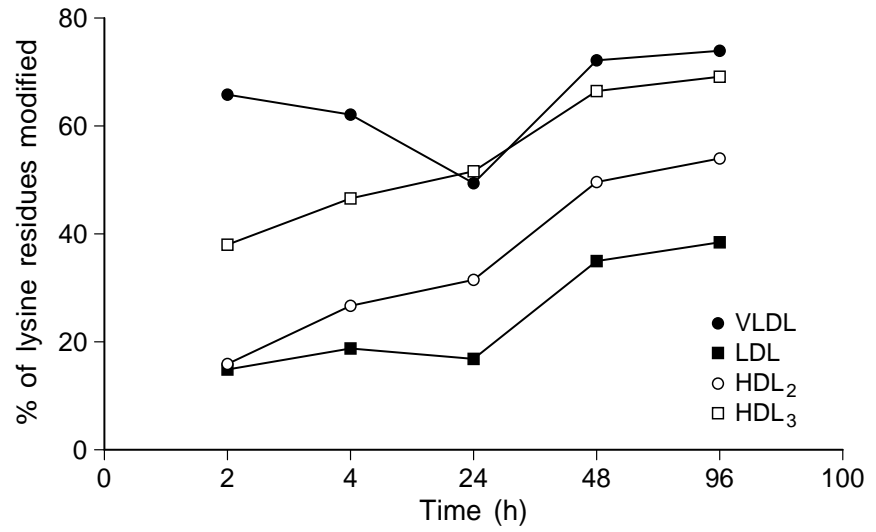

Fig. 3. Percent of protein lysine residues that were derivatized "in vitro" during glucose incubation of plasma LP vs time as shown in Figure 1. Percent of lysine residues modified were measured by the TNBS reaction in triplicate assays
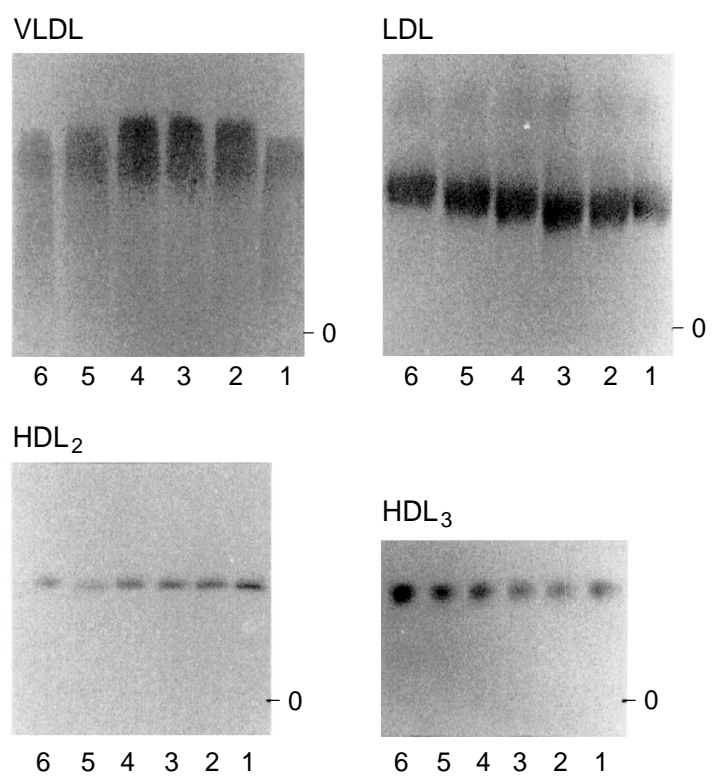

Fig. 4. Lipoprotein migration on $1 \%$ agarose gel. Oil red $\mathrm{O}$ staining was utilized for apoB-containing LP and Sudan black for HDL subfractions. Sample application origin indicated as O. Lipoproteins were glycated as shown in Figure 1. Migration lanes indicated on the bottom of the figures: $1=$ non-glycated control; 2 through 6 according to the glycation sequence at 2 , 4, 24, 48 and $96 \mathrm{~h}$ of incubation, respectively. Gel migration rate along time on LP glycation was faster for VLDL and LDL, and not modified for $\mathrm{HDL}_{2}$ and $\mathrm{HDL}_{3}$

Transfer of ${ }^{14} \mathrm{C}$-cholesteryl ester from HDL to $L D L$ or VLDL.

The transfer of radioactive cholesteryl oleate from HDL to apoB-containing from normal donors and diabetic subjects was measured during 2 and $4 \mathrm{~h}$ incubation periods and represents the percent transfer properly corrected for microgram of protein of the acceptor LP (LDL or VLDL) (Table 1). Greater transfer values were found between LP of diabetic as compared to those of control subjects. This difference 
Table 1. Percent transfer of ${ }^{14} \mathrm{C}$-cholesteryl oleate from HDL to LDL or VLDL

\begin{tabular}{|c|c|c|c|c|}
\hline \multirow[t]{2}{*}{ Incubation time } & \multicolumn{2}{|l|}{ HDL2 c } & \multicolumn{2}{|l|}{ HDL2 D } \\
\hline & $2 \mathrm{~h}$ & $4 \mathrm{~h}$ & $2 \mathrm{~h}$ & $4 \mathrm{~h}$ \\
\hline LDLc/Ic & $\begin{array}{l}0.026 \\
(0.017-0.039)\end{array}$ & $\begin{array}{l}0.056 \\
(0.047-0.063)\end{array}$ & $\begin{array}{l}0.033^{\mathrm{a}} \\
(0.025-0.040)\end{array}$ & $\begin{array}{l}0.060 \\
(0.042-0.077)\end{array}$ \\
\hline $\mathrm{LDLd} / \mathrm{Ic}$ & $\begin{array}{l}0.037 \\
(0.011-0.050)\end{array}$ & $\begin{array}{l}0.075^{\mathrm{a}} \\
(0.062-0.093)\end{array}$ & $\begin{array}{l}0.042^{\mathrm{a}} \\
(0.031-0.055)\end{array}$ & $\begin{array}{l}0.078^{\mathrm{a}} \\
(0.067-0.092)\end{array}$ \\
\hline LDLc/Id & $\begin{array}{l}0.032 \\
(0.025-0.038)\end{array}$ & $\begin{array}{l}0.054 \\
(0.039-0.068)\end{array}$ & ND & ND \\
\hline VLDLc/Ic & $\begin{array}{l}0.045 \\
(0.020-0.11)\end{array}$ & $\begin{array}{l}0.060 \\
(0.040-0.090)\end{array}$ & $\begin{array}{l}0.030 \\
(0.010-0.070)\end{array}$ & $\begin{array}{l}0.060 \\
(0.010-0.080)\end{array}$ \\
\hline VLDLd/Ic & $\begin{array}{l}0.100^{\mathrm{a}} \\
(0.060-0.170)\end{array}$ & $\begin{array}{l}0.165^{\mathrm{a}} \\
(0.130-0.280)\end{array}$ & $\begin{array}{l}0.125^{\mathrm{a}} \\
(0.030-0.190)\end{array}$ & $\begin{array}{l}0.130^{\mathrm{a}} \\
(0.090-0.200)\end{array}$ \\
\hline VLDLd/Id & \multicolumn{2}{|l|}{ HDL3 c } & \multicolumn{2}{|l|}{ HDL3 D } \\
\hline$\underline{\text { Incubation time }}$ & $2 \mathrm{~h}$ & $4 \mathrm{~h}$ & $2 \mathrm{~h}$ & $4 \mathrm{~h}$ \\
\hline LDLc/Ic & $\begin{array}{l}0.670 \\
(0.600-0.800)\end{array}$ & $\begin{array}{l}1.090 \\
(1.030-1.200)\end{array}$ & $\begin{array}{l}1.040^{\mathrm{a}} \\
(0.780-1.240)\end{array}$ & $\begin{array}{l}1.400^{\mathrm{a}} \\
(1.350-1.430)\end{array}$ \\
\hline LDLd/Ic & $\begin{array}{l}0.900^{\mathrm{a}} \\
(0.730-1.160)\end{array}$ & $\begin{array}{l}1.340^{\mathrm{a}} \\
(0.980-1.530)\end{array}$ & $\begin{array}{l}1.440^{\mathrm{a}} \\
(1.350-1.490)\end{array}$ & $\begin{array}{l}1.840^{\mathrm{a}} \\
(1.490-1.930)\end{array}$ \\
\hline LDLc/Id & $\begin{array}{l}0.710 \\
(0.490-0.900)\end{array}$ & $\begin{array}{l}1.040 \\
(0.800-1.080)\end{array}$ & ND & ND \\
\hline LDLd/Id & ND & ND & $\begin{array}{l}1.430^{\mathrm{a}} \\
(1.260-1.460)\end{array}$ & $\begin{array}{l}2.060^{\mathrm{a}} \\
(1.550-2.250)\end{array}$ \\
\hline
\end{tabular}

LP from normal control (c) or diabetic (d) subjects were incubated at $37^{\circ} \mathrm{C}$ or $4{ }^{\circ} \mathrm{C}$ for 2 or $4 \mathrm{~h}$ in the presence of plasma $\mathrm{d}>1.21 \mathrm{~g} / \mathrm{ml}$ from this subjects, respectively (Ic) and (Id), as the source of CETP. The amount of TG in the acceptor LP and of CE in the donor LP were identical in C and D LP. Percent transfer values (range) of ${ }^{14} \mathrm{C}-\mathrm{CO}$ from $\mathrm{HDL}$ to $\mathrm{LDL}$ or

in transfer rates was brought about by donor as well as by acceptor LP. Plasma infranatant $(\mathrm{d}>1.21 \mathrm{~g} / \mathrm{ml})$ utilized as the source of CETP did not influence the transfer rate when diabetic patients were compared to normal control subjects.

The percent transfer of radiolabelled cholesteryl ester from HDL subfractions to LDL during $4 \mathrm{~h}$ incubations is shown in Table 2. Glycation of the donor and acceptor LP simultaneously, effectively increased the transfer rate when compared to the values observed between control lipoproteins. Also "in vitro" glycation of HDL alone appears to play the major role in enhancing the transfer rate. Furthermore, the extent of transfer was significantly greater from $\mathrm{HDL}_{3}$ than from $\mathrm{HDL}_{2}$.

The percent transfer values of ${ }^{14} \mathrm{C}$-cholesteryl ester from $\mathrm{HDL}_{2}$ to LDL, shown as median (range) of the quintuplicate samples incubated, were: normal control subjects $27 \%(25-30)$; $\mathrm{HDL}_{2}$ pre-treated either with glucose $26 \%$ (25-29), or with $\mathrm{NaCNBH}_{3}$ $17 \%$ (14-27) alone, or after pre-treatment with
VLDL were obtained after precipitation with dextran sulphate $/ \mathrm{MgCl}_{2}$ solution and corrected for microgram of apoB protein

Comparisons among groups $(n=10)$ by the Mann-Whitney test are indicated: ${ }^{a} p<0.05$ compared to HDLc-LDLc/Ic or HDLc-VLDLc/Ic; ND, not determined

glucose and $\mathrm{NaCNBH}_{3} 27 \%$ (20-33). Therefore, the presence of $\mathrm{NaCNBH}_{3}$ in the incubation medium and its resultant product - glycyllysine - does not explain the enhanced transfer rate elicited by LP glycation.

The influence of glycation time on the percent transfer of ${ }^{14} \mathrm{C}$-cholesteryl ester from HDL to LDL was investigated by incubating $\mathrm{HDL}_{3}$ with glucose and $\mathrm{NaCNBH}_{3}$ for 2 to $96 \mathrm{~h}$ (Table 3). As compared to the control LP, glycation of HDL for under $48 \mathrm{~h}$ did not modify the rate of transfer. However, the $96 \mathrm{~h}$ glycation significantly increased the percent transferred.

Reconstituted HDL was utilized to assess the influence of the independent glycation of the lipid or of the protein moiety on the cholesteryl ester transfer process. Glycation of the protein component enhanced the rates of cholesteryl ester transfer to LDL or VLDL, whereas glucose incorporation in the lipid fraction of HDL played no role. Unexpectedly, when the two components of HDL (lipids and proteins) 
Table 2. Percent transfer of ${ }^{14} \mathrm{C}$-cholesteryl ester $\left({ }^{14} \mathrm{C}-\mathrm{CE}\right) \mathrm{E}$ HDL to LDL

\begin{tabular}{lll}
\hline & \multicolumn{2}{l}{$\%$ transfer of ${ }^{14} \mathrm{C}-\mathrm{CE}$} \\
\cline { 2 - 3 } & Median & Range \\
\hline HDL $_{2}$ C-LDLC & 22.5 & $12.0-32.5$ \\
$\mathrm{HDL}_{2}$ G-LDLC & 27.5 & $13.0-33.0$ \\
$\mathrm{HDL}_{2}$ C-LDLG & 20.0 & $14.0-36.0$ \\
$\mathrm{HDL}_{2}$ G-LDLG & $28.0^{\mathrm{a}, \mathrm{b}}$ & $22.0-33.0$ \\
$\mathrm{HDL}_{3}$ C-LDLC & $30.0^{\mathrm{e}}$ & $19.0-37.0$ \\
$\mathrm{HDL}_{3}$ G-LDLC & $36.0^{\mathrm{f}}$ & $26.5-47.0$ \\
$\mathrm{HDL}_{3}$ C-LDLG & $29.0^{\mathrm{g}}$ & $25.0-37.0$ \\
$\mathrm{HDL}_{3}$ G-LDLG & $37.0^{\mathrm{c}, \mathrm{d}, \mathrm{h}}$ & $31.0-42.0$ \\
\hline
\end{tabular}

Control (C) or glycated (G) LP were incubated at $37^{\circ} \mathrm{C}$ or $4^{\circ} \mathrm{C}$ for $4 \mathrm{~h}$ in the presence of plasma $\mathrm{d}>1.21 \mathrm{~g} / \mathrm{ml}$ as the source of CETP. Percent transfer values of ${ }^{14} \mathrm{C}$-CE from $\mathrm{HDL}$ to $\mathrm{LDL}$ were obtained after precipitation with dextran sulfate $/ \mathrm{MgCl}_{2}$ solution (see text for details)

Comparisons among groups $(n=10)$ by the Mann-Whitney test are indicated: ${ }^{\mathrm{a}} \mathrm{p}<0.05$ compared to $\mathrm{HDL}_{2} \mathrm{C}-\mathrm{LDLC} ;{ }^{\mathrm{b}} \mathrm{p}<0.05$ compared to $\mathrm{HDL}_{2} \mathrm{C}-\mathrm{LDLG}^{\mathrm{c}} \mathrm{p}<0.001$ compared to $\mathrm{HDL}_{3} \mathrm{C}$ - LDLC; ${ }^{\mathrm{d}} \mathrm{p}<0.05$ compared to $\mathrm{HDL}_{3} \mathrm{C}-\mathrm{LDLG} ;{ }^{\mathrm{e}} \mathrm{p}<0.05$, ${ }^{\mathrm{f}} \mathrm{p}<0.001,{ }^{\mathrm{g}} \mathrm{p}<0.05,{ }^{\mathrm{h}} \mathrm{p}<0.001$ compared to respective $\mathrm{HDL}_{2}$

Table 3. Influence of time-dependent glycation on the percent transfer of ${ }^{14} \mathrm{C}$-cholesteryl ester $\left({ }^{14} \mathrm{C}-\mathrm{CE}\right)$ from HDL to LDL

\begin{tabular}{llll}
\hline & $\begin{array}{l}\text { Glycation duration } \\
\text { (hours) }\end{array}$ & \multicolumn{2}{l}{$\begin{array}{l}\% \text { transfer } \\
\text { of }{ }^{14} \mathrm{C}-\mathrm{CE}\end{array}$} \\
\cline { 3 - 4 } & & Median & Range \\
\hline $\mathrm{HDL}_{3}$ C-LDLC & - & 25.0 & $24.0-30.0$ \\
$\mathrm{HDL}_{3}$ G-LDLC & 02 & 29.0 & $22.0-32.0$ \\
& 08 & 27.0 & $22.0-27.0$ \\
& 24 & 26.0 & $24.0-30.0$ \\
& 48 & 25.0 & $20.0-30.0$ \\
& 96 & $34.0^{\mathrm{b}}$ & $29.0-37.0$ \\
\hline
\end{tabular}

LP were glycated with a $200 \mathrm{mmol} / \mathrm{l}$ glucose and $\mathrm{NaCNBH}_{3}$ solution at $37^{\circ} \mathrm{C}$ at different intervals of time. Experimental groups $(n=5)$ included control $(\mathrm{C})$ or glycated $(\mathrm{G}) \mathrm{HDL}_{3}$ and control (C) LDL, as donor and acceptor of esterified cholesterol, respectively. Percent transfer values were obtained after incubation for $4 \mathrm{~h}$ at $37^{\circ} \mathrm{C}$ or $4{ }^{\circ} \mathrm{C}$ and precipitation of apoB $\mathrm{LP}$ with dextran sulfate $/ \mathrm{MgCl}_{2}$ solution (see text for details), ${ }^{\mathrm{a}}$ Incubated without glucose for $96 \mathrm{~h},{ }^{\mathrm{b}} \mathrm{p}<0.05$ by Mann-Whitney test compared to both control and to $2,8,24,48 \mathrm{~h}$ of glycation

were simultaneously glycated the enhanced transfer rate ascribed to the protein fraction was cancelled (Table 4).

CETP activity was markedly impaired by its "in vitro" glycation: when $\mathrm{HDL}_{2}$ was incubated with $\mathrm{LDL}$ and highly purified CETP, the median (range) percent transfer values were $23 \%$ (11-29) with control CETP, and 3.3\% (0-9) with glycated CETP. Diminished CETP activity was also observed in similar experiments $(n=4)$ when incubations of CETP were carried out only in the presence either of $\mathrm{NaCNBH}_{3}$ or glucose: CETP control $=11 \%(10-16)$; CETP plus glucose $=6 \% \quad(2-8)$; $\mathrm{CETP}$ plus $\mathrm{NaC}$ $\mathrm{NBH}_{3}=0.6 \%(0-2.2)$.
Table 4. Percent transfer of ${ }^{14} \mathrm{C}$-cholesteryl oleate $\left({ }^{14} \mathrm{C}-\mathrm{CO}\right)$ from HDL to LDL or VLDL by the influence of the lipid or protein component glycation

\begin{tabular}{lllll}
\hline & rec C & rec LG & rec PG & rec LPG \\
\hline LDL C & 72.5 & 71.5 & $76.5^{\mathrm{a}, \mathrm{b}}$ & $73.4^{\mathrm{e}}$ \\
LDL G & $71.8^{\mathrm{d}}$ & 70.0 & $75.5^{\mathrm{a}, \mathrm{b}}$ & 69.0 \\
VLDL C & 40.0 & 38.0 & $47.0^{\mathrm{b}, \mathrm{c}}$ & 37.0 \\
VLDL G & 38.5 & 36.5 & $47.5^{\mathrm{b}, \mathrm{c}}$ & 39.0 \\
\hline
\end{tabular}

Reconstituted (rec) HDL was made by sonication of the "in vitro" glycated lipid and protein components of the HDL. The transfer of ${ }^{14} \mathrm{C}-\mathrm{CO}$ from HDL to LDL or VLDL was measured in 4 and $3 \mathrm{~h}$ incubations, respectively. $\mathrm{G}=$ glycated; $\mathrm{C}=$ control; $\mathrm{LG}=$ recHDL with the lipid component G; $\mathrm{PG}=$ recHDL with the protein component G; LPG = recHDL with both lipid and protein components $\mathrm{G}$

Comparison among the groups by the Mann-Whitney test $(\mathrm{n}=10),{ }^{\mathrm{a}} \mathrm{p}<0.0005$ in comparison to rec $\mathrm{C} ;{ }^{\mathrm{b}} \mathrm{p}<0.0001$ in comparison to rec LG and rec LPG; ${ }^{c} p<0.05$ in comparison to rec $\mathrm{C} ;{ }^{\mathrm{d}} \mathrm{p}<0.05$ in comparison to $\mathrm{LG}$ and $\mathrm{LPG} ;{ }^{\mathrm{e}} \mathrm{p}<0.05$ in comparison to $\mathrm{LG}$

\section{Discussion}

Previous studies have indicated that the transfer of cholesteryl ester from HDL to lighter density LP is altered in the diabetic state [3-7]. Nonetheless, the primary cause of an increased transfer rate has recently been ascribed to an elevated plasma concentration of LP that are acceptors of cholesteryl ester $[6,24]$. In this regard the plasma concentration of CETP is consistently within the normal range in diabetic patients $[4,24]$. One study claims that micro and macroalbuminuria relates to CETP alteration in diabetes mellitus [23]; however, the CETP mass was indirectly measured. Conceivably the presence of albuminuria and not diabetes itself might bring on a rise in plasma CETP concentration since the latter is known to occur in the nephrotic syndrome [47].

The present study investigates the possibility that glycation of the plasma LP might explain the greater transfer of cholesteryl ester from HDL to the atherogenic LP, mediated by CETP, provided that the plasma levels of the latter are not raised by diabetes. This possibility is supported by the fact that glycation of plasma LP is elevated in diabetic subjects, which relates to several lipid and LP disturbances in this disease $[1,32,48,49]$.

In our study the "in vitro" concentrations of triglycerides from the acceptor LP and of cholesteryl ester from the donor LP were identical in the samples of the diabetic subjects and of the normal control subjects. Furthermore, transfer rates were also corrected for the concentration of the apoB. Significantly greater transfer rates of cholesteryl ester from HDL to LDL or VLDL were observed in the LP of diabetic patients which could relate to the elevated level of glycated haemoglobin that reflects poor glycaemic control. Furthermore, this finding agrees with the 
greater transfer rate that takes place due to the LP glycation "in vitro".

The phospholipid glycation, particularly of phosphatidylethanolamine, reported here, agrees with previous data by Cerami et al. [49] where this spontaneous biochemical reaction was associated with the genesis of the LP oxidation and, as indicated by others, to the clinical complications of diabetes [48]. However, in the present study, the absence of elevated TBARS in glycated LP indicates that oxidation is low, perhaps due to the presence of EDTA in the medium. Glycation of the lipid component alone in the reconstituted HDL did not influence the CETP activity. On the contrary, glycation of the protein fraction of the rec-HDL was responsible for the faster CETP-mediated transfer of cholesteryl ester to the apoB-containing LP.

Incubation of partially purified CETP with sodium cyanoborohydride and glucose markedly diminished the cholesteryl ester transfer rate. However, CETP activity was independently affected by incubation with glucose or with $\mathrm{NaCNBH}_{3}$ alone. Treatment of $\mathrm{HDL}_{2}$ with sodium cyanoborohydride alone did not influence the HDL cholesteryl ester transfer rate to LDL, and thus cannot explain the increased transfer rate elicited by glycation in the presence of cyanoborohydride.

Mechanisms whereby LP and CETP glycation interfere with lipid transfer between HDL and LDL were not considered in this study, but chemical analyses of the LP (data are not shown) did not disclose any difference between the glycated and normal LP in regard to their protein, triglycerides, unesterified and esterified cholesterol or phospholipid contents. Conceivably, LP particle modification by glucose enhances the affinity of CETP to the LP. Our results resemble a previous study where LP acetylation and succinylation stimulate the transfer of cholesteryl ester from HDL to LDL [50].

It has been shown that CETP-LP interactions take place through hydrophobic and electrostatic affinity between CETP positive and LP negative surface sites $[2,12]$. Glycation is known to mask positive Lys residues that alone could sharply impair the CETP affinity for the LP. Even the N-glycosylation that takes place during translation, when oligosacharides and sialic acid are added to the CETP asparagine, may influence the CETP role on the transfer of neutral lipids $[12,51]$. However, our transfer studies utilizing diabetic plasma as the source of CETP indicate that glycation of the latter does not seem to occur in these patients.

Several papers suggest that the transfer rate of cholesteryl ester from HDL to apoB-containing LP is enhanced in IDDM and NIDDM [3-7], and seemingly relates to the level of haemoglobin glycation $[4,6,7,23]$. Nonetheless, because of the apparently contradictory effects of this modification on different LP classes it is uncertain whether LP glycation in the diabetic plasma bears a relationship to atherogenesis. For instance, glycation of LDL might be atherogenic to the extent that it slows down the LDL turnover $[26,32]$, therefore raising the concentration of LDL in plasma. Glycation of HDL, on the other hand, markedly accelerates its turnover in plasma [31], and thus its faster transfer rate of cholesteryl ester to LDL shown "in vitro" may not be relevant to the "in vivo" process of reverse cholesterol transport that takes place in the plasma compartment. Nonetheless, from the arterial wall view point, a greater cholesteryl ester content of the atherogenic LP made available to the macrophages consequently to the glycation should aggravate the development of atherosclerosis $[34,52]$. In this regard, the first step of the reverse cholesterol transport, that is, the rate of cholesterol removal from the cell by HDL is impaired by the LP glycation [28, 33, 35]. Since CETP also participates in the uptake of cell cholesterol by HDL [53], glycation of CETP might also influence the process of cell cholesterol removal. Thus, uncontrolled diabetes potentially favours the arterial wall cholesterol accumulation secondarily to the interplay of several steps along the reverse cholesterol transport pathway involving glycation of LCAT, CETP, HDL and LDL that impairs the removal of cell cholesterol and its esterification rate while simultaneously favouring the cholesterol enrichment of the atherogenic LP and its uptake by the macrophages. At present it is not known which step is preferentially modified by diabetes at the arterial intima site.

A cknowledgements. The authors are thankful to Wagner V. Dominguez for the electrophoretic analyses and acknowledge the continuous support from Fundação Faculdade de Medicina and LIM (Clinical Hospital). This work was made possible due to grants HL 29582 from the National Institutes of Health (USA) to R.E.M, and 95/2851-8 from FAPESP (SP, Brazil) to E.C.R.Q.

\section{References}

1. Bierman EL (1992) Atherogenesis in diabetes. Artherioscler Thromb 12: 647-656

2. Tall AR (1993) Plasma cholesteryl ester transfer protein. J Lipid Res 34: 1255-1274

3. Bagdade JD, Ritter MC, Subbaiah PV (1991) Accelerated cholesteryl ester transfer in patients with insulin-dependent diabetes mellitus. Eur J Clin Invest 21: 161-167

4. Bagdade JD, Subbaiah PV, Otto ME, Ritter MC (1993) Accelerated cholesteryl ester transfer in noninsulin-dependent diabetes mellitus. Atherosclerosis 104: 69-77

5. Elchebly M, Porokhov B, Pulcini T, Berthezene F, Ponsin G (1996) Alterations in composition and concentration of lipoproteins and elevated cholesteryl ester transfer in noninsulin-dependent diabetes mellitus (NIDDM). Atherosclerosis 123: 93-101

6. Sutherland WH, Walker RJ, Lewis-Barned NJ, Pratt H, Tillman HC (1994) Plasma cholesteryl ester transfer in patients with non-insulin dependent diabetes mellitus. Clin Chim Acta 231: 29-31 
7. Ritter MC, Bagdade JD (1994) Contribution of glycaemic control, endogenous lipoproteins and cholesteryl ester transfer protein to accelerated cholesteryl ester transfer in IDDM.Eur J Clin Invest 24: 607-614

8. Reichl D (1994) Extravascular circulation of lipoproteins: their role in reverse transport of cholesterol. Atherosclerosis 105: 117-129

9. Barrans A, Jaspard B, Barbaras R, Chap H, Perret B, Collet X (1996) Pre- $\beta$ HDL: structure and metabolism. Biochim Biophys Acta 1300: 73-85

10. Fielding CJ, Fielding PE (1995) Molecular physiology of reverse cholesterol transport. J Lipid Res 36: 211-228

11. Quintão ECR (1995) Is reverse cholesterol transport a misnomer for suggesting its role in the prevention of atheroma formation? Atherosclerosis 116: 1-14

12. Lagrost L (1994) Regulation of cholesteryl ester transfer protein (CETP) activity: review of in vitro and in vivo studies. Biochim Biophys Acta 1215: 209-236

13. Ko KWS, Ohnishi T, Yokoyama S (1994) Triacylglycerol transfer is required for net cholesteryl ester transfer between lipoproteins in plasma by lipid transfer protein. J Biol Chem 269: 28206-28213

14. Marcel YL, McPherson R, Hogue M et al. (1990) Distribution and concentration of cholesteryl ester transfer protein in plasma of normolipidemic subjects. J Clin Invest 85: 10 17

15. Liu XQ, Bagdade JD (1995) Neutral lipid mass transfer among lipoproteins in plasma from normolipidemic subjects is not an equimolar heteroexchange. J Lipid Res. 36: 2574-2579

16. Marotti KR, Castle CK, Boyle TP, Lin AH, Murray R, Melchior GW (1993) Severe atherosclerosis in transgenic mice expressing simian cholesteryl ester transfer protein. Nature 364: $73-75$

17. Tall A, Granot E, Brocia R, Hesler C, Williams K, Denke M (1987) Accelerated transfer of cholesteryl esters in dyslipidemic plasma J Clin Invest 79: 1217-1225

18. Quinet E, Tall A, Ramakrishnan R, Rudel L (1991) Plasma lipid transfer protein as a determinant of the atherogenicity of monkey plasma lipoproteins. J Clin Invest 87: 1559-1566

19. Bagdade JD, Ritter MC, Subbaiah PV (1991) Accelerated cholesteryl ester transfer in plasma of patients with hypercholesterolemia. J Clin Invest 87: 12591265

20. Mann CJ, Yen FT, Grant AM, Bihain BE (1991) Mechanism of cholesteryl ester transfer in hypertriglyceridemia. J Clin Invest 88: 2059-2066

21. Grass DS, Saini U., Felkner RH et al. (1995) Transgenic mice expressing both human apolipoprotein $\mathrm{B}$ and human CETP have a lipoprotein cholesterol distribution similar to that of normolipidemic humans. J Lipid Res 36: 10821091

22. Zhong S, Sharp DS, Grove, JS et al. (1996) Increased coronary heart disease in Japanese-American men with mutation in the cholesteryl ester tranfer protein gene despite increased HDL levels. J Clin Invest 97: 2917-2923

23. Dullaart RPF, Groener JEM, Dikkeschei LD, Erkelens DW, Doorenbos H (1989) Increased cholesteryl ester transfer activity in complicated type 1 (insulin-dependent) diabetes mellitus - its relationship with serum lipids. Diabetologia 32: 14-19

24. Lottenberg SA, Lottenberg AM, Nunes VS, McPherson R, Quintão ECR (1996) Plasma cholesteryl ester transfer protein concentration, high-density lipoprotein cholesterol esterification and transfer rates to lighter density lipoproteins in the fasting state and after a test meal are similar in type II diabetics and normal controls. Atherosclerosis 127: $81-90$
25. Fielding CJ, Reaven GM, Liu G, Fielding PE (1984) Increased free cholesterol in plasma low and very low density lipoproteins in non-insulin-dependent diabetes mellitus: its role in the inhibition of cholesteryl ester transfer. Proc Natl Acad Sci USA 81: 2512-2516

26. Witztum JL, Mahoney EM, Branks MJ, Fisher M, Elam R, Steinberg D (1982) Nonenzymatic glucosylation of lowdensity lipoprotein alters its biologic activity. Diabetes 31: 283-291

27. Yamamoto M, Ranganathan S, Kottke B A (1986) Metabolism of glycosylated very-low-density lipoproteins in human skin fibroblasts. Biochim Biophys Acta 875: 410-413

28. Duell PB, Oram JF, Bierman EL (1990) Nonenzymatic glycosylation of HDL resulting in inhibition of high-affinity binding to cultured human fibroblasts. Diabetes 39: 12571263

29. Mamo JCL, Szeto L, Steiner G (1990) Glycation of very low density lipoprotein from rat plasma impairs its catabolism. Diabetologia 33: 339-345

30. Gugliucci Creriche A G, Stahl A J C (1993) Glycation and oxidation of human low density lipoproteins reduces heparin binding and modifies charge. Scand J Clin Lab Invest 53: $125-132$

31. Witztum J L, Fisher M, Pietro T, Steinbrecher UP, Elam RL (1982) Nonenzymatic glucosylation of high-density lipoprotein accelerates its catabolism in guinea pigs. Diabetes 31: 1029-1032

32. Steinbrecher U P, Witztum J L (1984) Glucosylation of lowdensity lipoproteins to an extent comparable to that seen in diabetes slows their catabolism. Diabetes 33: 130-134

33. Fournier N, Myara I, Atger V, Moatti N (1995) Reactivity of lecithin-cholesterol acyl transferase (LCAT) towards glycated high-density lipoproteins (HDL).Clin Chim Acta 234: 47-61

34. Klein RL, Laimins M, Lopes-Virella MF (1995) Isolation, characterization, and metabolism of glycated and nonglycated subfractions of low density lipoproteins isolated from type I diabetic patients and no diabetic subjects. Diabetes 44: 1093-1098

35. Fievet C, Theret N, Shojaee N, et al. (1992) Apolipoprotein A-I containing particles and reverse cholesterol transport in IDDM. Diabetes 41: 81-85

36. Havel RJ, Eder HA, Bragdon JH (1955) The distribution and chemical composition of ultracentrifugally separated lipoproteins in human serum. J Clin Invest 34: 1345-1353

37. Dobiasova MJ, Stribrna J, Sparks DL, Pritchard PH, Frohlich JJ (1992) Cholesterol esterification rate in plasma depleted of very low density lipoproteins is controlled by the proportion of HDL2 and HDL3 subclasses: study in hypertensive and normal middle-aged and septuagenarian men. J Lipid Res 33: 1411-1418

38. Mangold HK (1969) Aliphatic lipids. In: Stahl E (ed) Thin layer chromatography. A laboratory handbook $2^{\text {nd }}$ ed., Springer-Verlag, New York, pp. 375-388

39. Lowry OH, Rosebrough NJ, Farr AL, Randall RJ (1951) Protein measurement with the folin phenol reagent. J Biol Chem 193: 265-275

40. Bartlett G (1958) Phosphorus assay in column chromatography. J Biol Chem 234: 466-468

41. Morton R E, Zilversmit D B (1982) Purification and characterization of lipid transfer protein(s) from human lipoprotein-deficient plasma. J Lipid Res 23: 1058-1067

42. Parthasarathy S, Steinbrecher UR, Barnett J, Witztum JL, Steinberg D (1985) The essential role of phospholipase A2 activity in endothelial cell-induced modification of low density lipoprotein. Proc Natl Acad Sci USA 82: 3000-3004 
43. Habeeb AFSA (1966) Determination of free amino groups in proteins by trinitrobenzenesulfonic acid. Analytical Biochem 14: 328-336

44. Sargent JR (1969) Methods in zone electrophoresis 2nd edn. BDH Chemicals Ltd, UK

45. Nestler JE, Bamberger M, Rothblat G, Strauss III, JF (1985) Metabolism of high density lipoproteins reconstituted with $\left[{ }^{3} \mathrm{H}\right]$ cholesteryl ester and $\left[{ }^{14} \mathrm{C}\right]$ cholesterol in the rat, with special reference to the ovary. Endocrinology 117: 502-510

46. Guérin M, Dolphin PJ, Chapman MJ (1994) A new in vitro method for the simultaneous evaluation of cholesteryl ester exchange and mass transfer between HDL and apoB-containing lipoprotein subspecies. Arterioscler Thromb 14: 199-206

47. Moulin P, Appel GB, Ginsberg HN, Tall AR (1992) Increased concentration of plasma cholesteryl ester transfer protein in nephrotic syndrome: role in dyslipidemia. J Lipid Res. 33: 1817-1822
48. Lyons T J (1992) Lipoprotein glycation and its metabolic consequences. Diabetes 41: 67-73

49. Bucala R, Makita Z, Koschinsky T, Cerami, A, Vlassara H (1993) Lipid advanced glycosylation: pathway for lipid oxidation. Proc Natl Acad Sci USA 90: 6434-6438

50. Nishida HI, Arai H, Nishida T (1993) Cholesterol ester transfer mediated by lipid transfer protein as influenced by changes in the charge characteristics of plasma lipoproteins. J Biol Chem 268: 16352-16360

51. Stevenson SC, Wang S, Deng L, Tall AR (1993) Human plasma cholesteryl ester transfer protein consists of a mixture of two forms reflecting variable glycosylation at Asparagine 341. Biochemistry 32: 5121-5126

52. Sobenin IA, Tertov VV, Orekhov AN (1996) Atherogenic modified LDL in diabetes. Diabetes 45:S35-S39

53. Morton RE (1988) Interaction of plasma-derived lipid transfer protein with macrophages in culture. J Lipid Res 29: $1367-1377$ 